\title{
The Difficulties in Implementing Scientific Approach for Mathematics Learning
}

Bakher Nenotaek $^{1,}$ Imam Sujadi ${ }^{2}$, Sri Subanti ${ }^{3}$

\begin{tabular}{l} 
ARTICLE INFO \\
\hline Article History: \\
Received 05.04.2019 \\
Received in revised \\
form 02.07.2019 \\
Accepted \\
Available online \\
01.09.2019
\end{tabular}

\begin{abstract}
The learning system of Curriculum 2013 uses a scientific approach regulated in the Minister of Education and Culture Regulation Number 65 of 2013. The scientific approach emphasizes the importance of collaboration and cooperation among students in knowing and understanding various materials. The purpose of curriculum 2013 is making students are able to formulate a problem and study analytical thinking. However, in fact, teachers face difficulties in implementing the scientific approach. It is a descriptive qualitative study. Data is obtained through observation on the mathematics learning process of $X$ grade at Kupang city. The results reveal that there are several difficulties faced by the teachers in implementing the scientific approach. They are (1) difficulty in making students actively involved in the learning process, (2) difficulty in stimulating students to ask questions, (3) difficulty in making students formulate their own knowledge, and (4) difficulty in fostering the courage and language skills of students to communicate results.
\end{abstract}

(C) IJERE. All rights reserved

Keywords:

Difficulties, scientific approach, mathematics learning.

\section{INTRODUCTION}

The Regulation of Minister of Education and Culture number 81A on curriculum implementation states that the curriculum applied in education in Indonesia starting from the academic year of 2013/2014 is the 2013 curriculum. In the process of implementation, the government holds a trial (try out) in several schools. On 15 July 2013, the government begins in several schools. 2013 curriculum is a curriculum that optimizes the potential of students so it is expected that it will bring a positive impact. The purpose of developing the 2013 curriculum is producing Indonesian generation who are productive, creative, innovative, and affective through strengthening integrated attitudes, skills, and knowledge. Darsono (2017), The objective of education is to create high-quality generations that in turn can be competitive in education realm. The goal can be achieved through the implementation of education by improving the content of education, making a learning paradigm shift into constructivism, and using competency-based assessment and authentic class assessment (Jawa Pos).

One of the changes occurred in the 2013 curriculum is the demand for a learning process that must lead to creativity. Theoretically, learning in the 2013 curriculum, especially in mathematics is in line with the mathematics learning set by the National Council of Teachers of Mathematics (NCTM). Mathematics learning formulated by NCTM stipulates that students must learn mathematics through understanding and actively formulating new knowledge from experiences (NCTM, 2000). There are five standard processes in

\footnotetext{
${ }^{1}$ Student of Master of Mathhematics Education, Sebelas Maret University, bakhermadrid@gmail.com, orcid.org/0000-0002-6094-3209

${ }^{2}$ Lecture of Mathhematics Education, Sebelas Maret University, imamsujadi@staff.uns.ac.id, orcid.org/0000-0002-8302-2234

${ }^{3}$ Lecture of Mathhematics Education, Sebelas Maret University, sri.subanti@uns.ac.id, orcid.org/0000-0002-2493-4583
} 
Nenotaek,B., Sujadi,I. \& Subanti,S. (2019). The difficulties in implementing scientific approach for mathematics learning. International Journal of Educational Research Review, 4(4),624-636.

mathematics learning, namely: (1) learning to solve problems; (2) learning to give reason and proof; (3) learning to communicate; (4) learning to associate ideas; and (5) learning to present ideas (NCTM, 2000). Learning the concept of NCTM is almost the same as learning using the scientific approach regulated by the Minister of Education and Culture Number 65 of 2013. The scientific approach contains the stages of observing, formulating problems, submitting or formulating hypotheses, collecting data with various techniques, analyzing data, drawing a conclusion, and communicating concepts, laws, or principles (Daryanto, 2014; Vaulina, 2015).

In the learning condition of the 2013 curriculum, students are directed to formulate problems and practice analytical thinking. The teacher is expected to create a learning process referring to the Standard Process that contains exploration, elaboration, and confirmation. The learning process also prioritizes the students to observe, ask, formulate, conclude, and communicate so that they can properly master the material (Mendikbud, 2013). One of the ways to realize the learning process using the 2013 curriculum is the change of the teacher's paradigm. However, changing the teacher's paradigm in teaching is not an easy thing to do, because the teacher tends to use conventional teaching styles by explaining and recording material on the board. Meanwhile, in the 2013 curriculum with a scientific approach, a teacher is required to understand and be able to apply the approach and learning models well, as well as the use of varied media and learning resources (Mayang, 2015).

Regarding the fact, the government holds training for teachers and provides supporting books for teachers and students in order to support the implementation of the 2013 curriculum. The training is conducted as a means for teachers to improve understanding of the learning process. Although the 2013 curriculum has been applied thoroughly in 2015 but based on the data and monitoring process, the implementation is still not good enough. The results of a survey on the implementation of the 2013 curriculum in several regions in Indonesia show that the training had not been carried out evenly. Research conducted by Buchory (2013) states that there are still 1,300,163 teachers who must join training in the year of 2013. Meanwhile, the completion of the training for the academic year of 2014/2015 is still far from the target. The training target ends on the $30^{\text {th }}$ of June 2014 . There are only 707.000 out of 1.3 million teachers who have joined the training, and there are 353,557 teachers in the Junior High School level (Jawapos, 2014).

The implementation of a scientific approach that has been going on for several years shows that almost all teachers in Indonesia have participated in the training held by schools and organization. This shows the seriousness of the government in improving the ability of teachers and the quality of education in Indonesia because a teacher should have a wide range of professional competencies and skills. A teacher must have skills in managing his class. In addition, the skills a teacher must possess ar e skills for evaluating and assessing his or her students (Simsek, 2017). However, the facts show that there are still many teachers who experience difficulties in carrying out a scientific approach. It can be seen from several research results, such as the research conducted by Mayang (2015) which reveals that most science 
Nenotaek,B., Sujadi,I. \& Subanti,S. (2019). The difficulties in implementing scientific approach for mathematics learning. International Journal of Educational Research Review, 4(4),624-636.

teachers have not fully understood the scientific approach in the 2013 curriculum. While teaching, many teachers still explain and record on the board, so that the learning process is not centered on students, but still teacher-centered. The results of the research conducted by Ahmadi Susilo (2015) state that the implementation of learning by the research subjects have not fully described the scientific approach. The research results of Irfan Sandyoka (2016) also reveal that the difficulties experienced by economic teachers in applying to learn with a scientific approach are due to limited facilities and time, passive students, and inappropriate learning model. The results of these studies provide information that the implementation of the scientific approach to learning is still not going well.

The results of research in several regions in Indonesia such as Jambi, Surakarta, Semarang and others about the implementation of the scientific approach to learning that has not run optimally became the basis for conducting this research in Kupang city. Kupang city is one of the regions in Indonesia that has applied a scientific approach so it is possible to obtain data on the implementation of scientific learning. The results of author interview with one of the mathematics teachers at the piloting school / at the Senior High School level in Kupang City obtain information, namely (1) not all teachers have made complete learning tools; (2) the teaching and learning process mostly still uses the lecture method and it is dominated by teachers; and (3) some teachers have not shown their creativity in the learning process. Whereas the results of interview with one of the mathematics teacher at the school which has applied the 2013 curriculum are: (1) the difficulty regarding compulsory mathematics learning books that do not exist, as well as the distribution of mathematics books is late; (2) the difficulty of conditioning the class because there are too many students; (3) the difficulty in implementing scientific learning because students are lazy to find and shape their own knowledge.

Based on the results of previous studies in several regions as well as the results of preliminary interview with several teachers in Kupang, the researchers are interested in conducting research on the difficulties in implementing scientific approach experienced by Senior High School (SMA) mathematics teachers in Kupang. This study focused on mathematics teachers of X grade in Kupang City who had attended training on the 2013 curriculum so it is assumed that the teacher already had the ability and experience in conducting learning with the scientific approach. In addition, this research is conducted on mathematics teachers from two different schools; a school which applied the 2013 curriculum (piloting school) in a long period and teachers from a school that implemented the 2013 curriculum in a short period. Based on the selection of teachers, it is expected that the difficulties experienced by teachers can be found.

\section{Method}

The research is a qualitative descriptive. The research subjects are five mathematics teachers selected from two Senior High Schools in Kupang City. Fifth mathematics teacher consist from one man and four woman. Two teacher selected from Senior High Schools 2 Kupang City and other from Senior High Schools 
Nenotaek,B., Sujadi,I. \& Subanti,S. (2019). The difficulties in implementing scientific approach for mathematics learning. International Journal of Educational Research Review, 4(4),624-636.

4 Kupang City. The sampling technique is Purposive sampling. Documentation, interview, and observation are applied as a technique of collecting data. Documentation is intended to obtain data about the lesson plan. Observation is employed to obtain data related to teachers' difficulties in mathematics learning using a scientific approach at $\mathrm{X}$ grade. Meanwhile, an interview is intended to dig the data in depth related to teachers' difficulties in mathematics learning using a scientific approach.

Data for each subject from the three data sources are reduced to obtain the important main data. Therefore, valid data will be collected for each research subject. Valid data from each research subject will be the basis for drawing conclusion related to the difficulties in implementing the scientific approach for learning mathematics. Triangulation in the form of method triangulation by comparing the data from class observation, lesson plan documentation, and interview script are employed as data validity checking.

\section{Results}

The scientific approach regulated in the Minister of Education and Culture Regulation Number 65 of 2013 contains the stages of observing, questioning, Collecting data, associating, and communicating (Daryanto, 2014; Vaulina, 2015). Each stage of this activity should be carried out by the teachers to support the success of learning in the classroom. The results of the research for each subject are as follow.

a) Interview

Here is the transcript of the main interview that had been conducted in the data reduction:

Interviewer : In observing activities, you explains the material, gives examples of problems and completes the example, why?

Information 1 : I have to explain the materials thoroughly in order to make students understand. It is caused by the lack of learning resources and learning media.

Information $2:$ I explain the material due to the lack of learning media and learning sources. It is intended to facilitate observation activity

Information 3 : The students do not understand what will be achieved during the observation phase. It makes me face a problem.

Information $4:$ I explain the materials due to the lack of learning resources. It will increase students' understanding.

Information $5:$ I explain the materials due to the lack of learning resources. It will increase students' understanding.

Interviewer : In the Questioning, it appears that you often give questions, while students tend to be passive, why?

Information 1 : One of the fundamental problems is growing students' curiosity. If I do not ask them then the learning process will not run well.

Information 2 : One of the fundamental problems is growing their curiosity. If I do not ask them then the learning process will not run well. 
Information 3 : The involvement of students is very little. When I give the opportunity to ask questions, they will be silent.

Information 4 : When I give a chance to ask a question, the students are silent. When I give them questions, they can't answer.

Information 5 : When I give a chance to ask a question, the students are silent. When I give them a question, they can't answer. I face difficulty in making them ask.

Interviewer : When giving questions for students to solve, collecting data and associating, it appears that you goes around and sees how they solve the problem. It also appears that you explained to each student who asked, why?

Information 1 : When I give different tasks from the example, students have difficulty in solving it. It is caused by the lack of a learning resource to gather information. The number of students makes me face difficulty in managing effective learning because they can't formulate their own knowledge.

Information 2 : The students face difficulty when the teachers give different tasks from the example. It is caused by the lack of learning resources. Time allocation for discussion is too long because the students take a long time in finding their own knowledge.

Information 3 : The students do not understand the content of students' worksheet and how it will work. As a result, I must explain it to all of the students. The discussion process does not run well because there are only a few students who understand the material.

Information 4 : The students face difficulty when the teachers give different tasks from the example. It is caused by the lack of learning resources to gather information. The number of students makes me face difficulty in managing effective learning because students can't form their own knowledge. Information 5 : The students face difficulty when the teachers give different task from the example. It is caused by the lack of learning resources. I face difficulty because almost all of the students asking questions, so it takes a long time.

Interviewer : In the activity of communicating, it appears that you is active, while the students tend to be passive, why?

Information 1 : The students do not have a chance to present their work due to time allocation. Besides, they do not have the bravery to present their work.

Information 2 : The main problem is making students be brave to present their work.

Information 3 : The difficulty caused by the students who do not have the bravery to present their work and they do not understand what their goal is.

Information 4 : The difficulties caused by the students who do not have the bravery to present their work. They also do not understand what their goal is.

Information 5 : The difficulties caused by the students who do not have the bravery to present their work and they also do not understand what their goal is. 
b) Documentation

Based on documentation of lesson plan, the following results are obtained:

\section{Observing stages :}

1) Informan 1 : Students read and understand the problem solving of rational and irrational inequalities in textbook page 116-118 and 124-127

2) Informan 2 : Students observe and try to understand the problem of irrational inequality or the root form of a slide show.

3) Informan 3 : The teachers give tasks to be discussed.

4) Informan 4 : Observing worksheets for the materials of definition, completion, and the use of the three-variable linear equation system (SPLTV) by employing combination, substitution, or elimination method.

5) Informan 5 : Observing worksheets for the materials of definition, completion, and the use of the three-variable linear equation system (SPLTV) by employing combination, substitution, or elimination method.

\section{Questioning stages :}

1) Informan 1 : The questioning stage is not described by the teacher. The activity is not written in a lesson plan.

2) Informan 2 : The questioning stage is not described by the teacher. The activity is not written in a lesson plan.

3) Informan 3 : The teacher asks students to read and understand the problem individually and propose things that have not been understood regarding the problem.

4) Informan 4 : The students ask a question related to the materials of definition, completion, and the use of the three-variable linear equation system (SPLTV) by employing combination, substitution, or elimination method. It is intended to gather additional information.

5) Informan $5:$ The students ask a question related to the materials of definition, completion, and the use of the three-variable linear equation system (SPLTV) by employing combination, substitution, or elimination method. It is intended to gather additional information.

\section{Collecting data stages :}

1) Informan $1:$ The students gather information from various sources.

2) Informan $2:$ The students gather information from various sources.

3) Informan 3 : The students collect information from various sources related to tasks.

4) Informan $4:$ The students gather information to answer tasks.

5) Informan 5 : The students gather information to answer tasks.

\section{Associating stages :}

1) Informan $1:$ The students collaborate in a group to solve tasks. 
2) Informan 2 : The students collaborate in a group to solve tasks.

3) Informan 3 : The students collaborate in a group to solve tasks.

4) Informan 4 : The students collaborate in a group to solve tasks.

5) Informan 5 : The students collaborate in a group to solve tasks.

\section{Communicating stages :}

1) Informan $1:$ One of the groups presents their work in front of the class.

2) Informan 2 : One of the groups presents their work in front of the class.

3) Informan $3:$ One of the groups presents their work in front of the class.

4) Informan 4 : Delivering discussion result for the materials of definition, completion, and the use of three-variable linear equation systems (SPLTV) by employing combination, substitution, or elimination method.

5) Informan 5 : Delivering discussion result for the materials of definition, completion, and the use of three-variable linear equation systems (SPLTV) by employing combination, substitution, or elimination method.

c) Observation

Based on observation of mathematics learning using a scientific approach, the following results are obtained:

\section{Observing stages :}

1) Informan $1:$ The teachers face difficulty in observing stage because of the lack of learning resources and learning media. Observing stage is done by looking at the material written and explained by the teacher on the whiteboard. There is a mismatch. The observing activities written in the lesson plan are not implemented in the learning process.

2) Informan $2:$ The teachers face difficulty in observation activity because of inadequate learning resources and learning media. Observing stage is done by looking at the material written and explained by the teacher on the whiteboard. There is a mismatch. The observing activities written in the lesson plan are not implemented in the learning process.

3) Informan 3 : The teachers face difficulty in observation activity because of inadequate learning resources and learning media. Observing stage is done by looking at the material written and explained by the teacher on the whiteboard.

4) Informan 4 : The teachers face difficulty in observation activity because of inadequate learning resources and learning media. Observing stage is done by looking at the material written and explained by the teacher on the whiteboard.

5) Informan $5:$ The teachers face difficulty in observation activity because of inadequate learning resources and learning media. Observing stage is done by looking at the material written and explained by the teacher on the whiteboard.

\section{Questioning stages :}


1) Informan $1:$ The teachers have difficulty in making students actively involved in the learning process. Students are passive and silent so the teachers have to submit questions related to materials.

2) Informan $2:$ The teachers have difficulty in making students actively involved in the learning process. Students are passive and silent so the teachers must submit questions related to materials.

3) Informan 3 : The teachers have difficulty in making students ask questions related to materials. As a solution, the teachers submit questions to check students' understanding.

4) Informan 4 : The teachers have difficulty in making students ask questions related to materials because they are a passive learner. As a solution, the teachers ask questions to check students' understanding. When the teachers ask questions, they can't answer because they have low motivation in learning mathematics.

5) Informan $5:$ The teachers have difficulty in making students ask questions related to materials because they are a passive learner. As a solution, the teachers ask questions to check students' understanding. When the teachers ask questions, they can't answer because they have low motivation in learning mathematics.

\section{Collecting data stages :}

1) Informan 1 : This activity requires a lot of time. It is caused by the lack of learning resources so almost all students ask the teachers when experiencing difficulties. In addition, this condition makes a classroom atmosphere become crowded. It disturbs the focus and comfort of students in working on the tasks.

2) Informan 2 : Learning resources possessed by students only come from the teachers' notes. Therefore when the problem is different from the example, students have difficulty in collecting data to solve the problem.

3) Informan 3 : Learning resources possessed by students only come from the teacher's notes. Therefore when the problem is different from the example, students have difficulty in collecting data to solve the problem.

4) Informan 4 : The activity doesn't run well because of inadequate learning resources. The teachers must guide each student. It takes a long time because there are many students.

5) Informan 5 : The activity doesn't run well because of inadequate learning resources. The teachers must guide each student. It takes a long time because there are many students.

\section{Associating stages :}

1) Informan $1:$ The teachers have difficulty in this stage because almost all of the students are unable to work together in solving tasks. The teachers must help them to solve the existing problem by explaining it repeatedly. 
2) Informan 2 : The activity doesn't run well because of inadequate learning resources. The teachers must guide each student. It takes a long time because there are many students.

3) Informan 3 : The teachers' difficulty caused by the number of students who unable to cooperate in solving tasks. The teachers must help them and explain the material repeatedly.

4) Informan 4 : The teachers' difficulty caused by the number of students who unable to cooperate in solving tasks. The teachers must help them and explain the material repeatedly.

5) Informan 5 : The teachers' difficulty caused by the number of students who unable to cooperate in solving tasks. The teachers must help them and explain the material repeatedly.

\section{Communicating stages :}

1) Informan $1:$ The students face difficulty in presenting their work. While the teachers have difficulty in motivating students to come forward.

2) Informan 2 : The students face difficulty in presenting their work. While the teachers have difficulty in motivating students to come forward.

3) Informan 3 : The students face difficulty in presenting their work. Then, the teachers have difficulty in motivating students to present their work.

4) Informan 4 : The students face difficulty in presenting their work. The teachers have difficulty in motivating students to present their work.

5) Informan 5: The students face difficulty in presenting their work. Then, the teachers have difficulty in motivating students to present their work.

\section{Discussion and Suggestiions}

The scientific approach emphasizes the importance of collaboration and cooperation among students. Learning method and learning model are needed to accommodate cooperation among students. The scientific approach involves several stages, such as observing, questioning, collecting data, associating, and communicating. Each stage should be carried out by the teacher to support the success of learning in the classroom. The learning process with a scientific approach will run effectively if the teachers plan the learning process well. Based on the documentation of lesson plan (RPP), it appears that each teacher can arrange learning stages according to the scientific approach. However, based on the interview results, it is found that the existing lesson plans are prepared by Teacher Organization (MGMP) and do not develop by the teacher independently. This result is similar to the Susilo Ahmadi study (2015) that there are teachers who depend on Teacher Organization (MGMP) in planning learning process. A learning plan that does not work well will have an impact on the learning process. This is in line with the opinion of Mailani (2014) who states that the success of teaching and learning process is strongly supported by the ability of a teacher to design and compile a plan of learning. 
Based on the data, it is found that the difficulties faced by the experienced teacher and the new teacher are alike. Several problems found in the learning process using the scientific approach are interrelated between stages.

In observing stage, the teacher tends to be the center of learning and the class is more dominated by the teacher, students only receive the teachers' explanation without any feedback from students to argue. The results of this study are in line with Perwira's research (2015). Besides, the teaching method tends to be conventional, the teacher writes notes on the board, and the learning media limits. Interactive media that are compatible with a scientific approach such as visual video, PowerPoint slides, audio, LCD, computers, and internet are not available at the school. The results of this study are similar to the research of Ayuk Kusumastuti (2016) who states that teachers only use conventional media without involving students. The media are in the form of students' worksheet, whiteboards, and markers that did not attract the attention of students.

The lack of learning media making fun learning process has not yet been created. This also proves that teachers are still lack of ability to be a facilitator in the learning process. The unavailability of learning media gives impact to the learning process. It is in accordance with the opinion of Mulyasa (2007). He states that the use of technology in education and learning is intended to facilitate learning activities. These conditions should not be allowed because learning media play an important role in the teaching and learning process. Media is all means/forms of non-personal communication which is used as a forum for learning information that will be delivered to students. It can attract their interest and attention so that the goals of learning can be achieved (Hosnan, 2014).

In addition, the teacher explains the material in order to save learning time. The amount of material is too many, whereas the learning time is limited. It makes the teacher face difficulty in applying the scientific approach. Ideally, the learning process that uses the $5 \mathrm{M}$ stage emphasizes the students' participation and the meaningfulness of the material. However, some learning strategies based on scientific approach need a long time. As a consequence, most teachers express pessimism in implementing the learning process. The way to overcome the teachers' problem related to the time allocation is by giving tasks to the students and using the conventional method in teaching.

The questioning activity is one of the stages which have many problems. Students tend to be quiet at this stage. In fact, when "the teacher forces students" to ask questions, they often remain silent. The condition encourages the teacher to be more active in submitting questions to the students in order to stimulate their curiosity. However, this effort does not bring a good result. The students are not enthusiastic in learning mathematics because of their low motivation. They can't adjust student-centered learning. Most students are not active and pay little attention to the ongoing learning process. This result is similar to the researches which state that the majority of the students are passive due to their low motivation. It can be seen from the learning process. The students do their own activities, such as chatting with other friends (Irfan Sandyoka, 
Nenotaek,B., Sujadi,I. \& Subanti,S. (2019). The difficulties in implementing scientific approach for mathematics learning. International Journal of Educational Research Review, 4(4),624-636.

2015; Ningsih, 2014; Officer, 2015; Retnawati, 2015). The existing condition is certainly not in accordance with the implementation of a scientific approach. Various efforts have been made by the teacher, but the five teachers who become informants agree that the students are still difficult to ask questions in mathematics learning. The stage may run well if the teacher gives treatment patiently. However, it will take a long time. It is inappropriate with the time allocation in the learning process. As a solution, the teachers should skip the questioning stage. In general, the teachers only give them the time to ask and if there is no response then it is continued to the upcoming stage.

Other difficulties faced by the teachers are making students gather information and reasoning. The difficulties are caused by several factors, such as the ability of students is diverse; students are not familiar with a constructivist learning approach, learning time is limit, and learning facilities in the form of books is lack. Difficulties in gathering information arise because students do not understand the content of students' worksheet and how it will work. This difficulty is caused by students' lack of basic mathematical abilities, which can be seen from several examples, such as difficulty in performing multiplication and addition operations (with different marks). The results of this study are in line with the research of Eraslan (2013), Syomwene (2013), and Mizzi (2013). The diverse ability of students makes teachers difficult in planning active learning. Meanwhile, the implementation of mathematics learning will run well if the teacher can provide material in stages and know the initial characteristics of students. This is in accordance with the opinion of Hamalik (2009) who said that identifying students' initial abilities in learning is crucial because it greatly influences the effectiveness of the learning process. This statement is supported by Mulyasa (2014) who states that understanding the characteristics of students can provide optimal services according to their respective interests, talents, abilities, and potentials.

In the stage of communicating/presenting the results, it appears that the teachers have difficulty in making students brave to present the results and practice the language skills. It occurs because many students feel nervous and afraid to convey the answers. In addition, the difficulty is also caused by students' lack of understanding of what had been done. Besides, they do not know what they can present because the existing work is the result of other groups/other friends. On the other hand, this case is in contrast to one of the learning outcomes based on NCTM, namely the ability of students to present the results of their work.

Based on the research results, it can be concluded that there are similar difficulties among teachers from different schools. Several difficulties in implementing the scientific approach experienced by the mathematics teachers of $\mathrm{X}$ grade in Kupang City are 1) difficulty in making students actively involved in learning, 2) difficulty in making students actively ask question, 3) difficulty in making students formulate their own knowledge, 4) difficulty in fostering the courage and language skills of students to communicate results.

The suggestions for the teachers : 1) to be able to improve their understanding of activities in each scientific approach so that they can be applied properly in the mathematics learning process in the classroom 
so that the objectives of the 2013 curriculum can be achieved. 2) chool to hold training, monitoring, and evaluation regularly to the teacher in order to be able to carry out learning in accordance with the scientific approach.

\section{References}

Ayuk Kusumastuti, S. \&. (2016). Faktor-faktor Penghambat Guru dalam Melaksanakan Kurikulum 2013 pada Pembelajaran Akuntansi di SMK Negeri 3 Surakarta. Tata Arta, 118-133.

Buchory. 2013. “Problema Implementasi Kurikulum 2013”. Kedaulatan Rakyat. No. _ . 3 Januari.

Darsono, Winarno \& ST. Y. Slamet (2018). The need textbook writing of children's story based on character education. International Journal of Educational Research Review, 3(2), 1-8.

Daryanto. (2014). Pendekatan Pembelajaran Saintifik Kurikulum 2013. Yogyakarta: Gava Media.

Eraslan, A. (2013). Teachers' reflections on the implementation of the new elementary school mathematics curriculum in Turkey. HU Journal of of Education. 28 (2),152-165.

Hamalik, O. (2009). Psikologi Belajar Mengajar. Bandung: Sinar Baru Algensindo.

Hosnan. (2014). Pendekatan saintifik dan kontekstual dalam pembelajaran abad 21. Jakarta: Ghalia Indonesia.

Irfan Sandyoka, M. \&. (2016). Analisis Kesulitan Guru dalam Pembelajaran Ekonomi pada Kurikulum 2013 di Kelas X SMA Negeri 4 Kota Jambi.

Jawa Pos. (2014). Target Pelatihan Kurikulum Baru Sulit Tercapai. No. _. 25 Juni.

Majid, A. (2014). Implementasi Kurikulum 2013 Kajian Teoritis dan Praktis. Bandung: Interes Media.

Mayang A.D, Puspita. (2015). Identifikasi Kesulitan Guru IPA dalam Melaksanakan Pembelajaran Kurikulum 2013 di SMP Negeri 1 Wonogiri Tahun Pelajaran 2014/2015. Surakarta; Fakultas Keguruan dan Ilmu Pendidikan Universitas Muhammadiyah Surakarta.

Mendikbud. (2013). Permendikbud nomor 69 tentang Kerangka Dasar dan Struktur Kurikulum Sekolah Menengah Atas, Kompetensi. Jakarta.

Mendikbud. (2016). Permendikbud No 22 Tahun 2016 Tentang Standar Proses Pendidikan Dasar dan Menengah. Jakarta: Kementerian Pendidikan dan Kebudayaan.

Milles, M.B. \& Huberman, A.M. (1992). Qualitative data analysis, a sourcebook of new method. Beverly Hills : Sage Publication.

Mizzi, D. (2013). The challenges faced by science teachers when teaching outside their specific science specialism. Acta Didactica Napocensia, 6 (4) 1-6.

Mulyasa, E. (2014). Guru dalam Implementasi Kurikulum 2013. Bandung: PT. Remaja Rosdakarya.

National Council of Teacher of Mathematics (NTCM) (2000). Principles and standards for school mathematics. Reston, VA: NCTM.

Ningsih. (2015). Analisis Kesulitan Guru Matematika Kelas Vii Dalam Menerapkan Kurikulum 2013 Di Smp N 12 Surakarta. Surakarta; Fakultas Keguruan dan Ilmu Pendidikan Universitas Muhammadiyah Surakarta.

Perwira, D. E. (2015). Kendala-Kendala Implementasi Kurikulum 2013. JPTM, 21-28. 
Retnawati, H. (2015). Hambatan Guru Matematika Sekolah Menengah Pertama Dalam Menerapkan Kurikulum Baru. Cakrawala Pendidikan, Oktober 2015, Th. XXXIV, No. 3

Şimşek,Y. (2017). The evaluation of the application of transported education by teacher s. International Journal of Educational Research Review, 2(1), 41-48. DOI: 10.24331/ij ere.309972

Syomwene, A. (2013). Factors affecting teachers' implementation of curriculum reforms and educational policies in schools: The Kenyan experience. Journal of Education and Practice. 4 (22) 80-86.

Vaulina, J. (2015). Penerapan Pendekatan Saintifik dalam Pembelajaran Ekonomi SMA Kelas XI Materi Ketenagakerjaan. Jurnal: Universitas Negeri Surabaya. (25): 2-3. 